Historic, Archive Document

Do not assume content reflects current scientific knowledge, policies, or practices. 



\title{
Price List of Young
}

Ornamental Trees and Shrubs

\author{
For Planting in Nursery Rows
}

\section{THOMAS B. MEEHAN CO. \\ Dresher, 'Penna.}

The demand for this class of stock is far greater than the supply. Place your order now. We will reserve your stock for you, and ship by Freight or Express when and as directed.

Orders booked in rotation received.

\section{PLEASE READ TERMS}

No less than 10 plants sold of any one variety.

25 of any variety at the rate quoted per 100.

250 of any variety at the rate quoted per 1000 .

Packing charged extra.

When cash accompanies order, add 10 per cent. to cover packing charges

\section{NORWAY MAPLES}

Oregon grown trees, 5 to 6 feet. Strong, straight whips. Well rooted. Just the thing for planting in nursery rows to grow on. Sold in case lots only. Cases will not be broken to fill orders for smaller quantities.

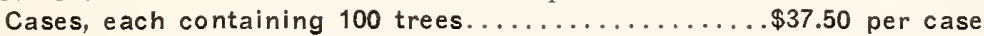

Cases, each containing 200 trees .............. 70.00 per case

Cases, each containing 250 trees .............. 85.00 per case

Prices are for the trees here at Dresher and include the cost of box and packing.

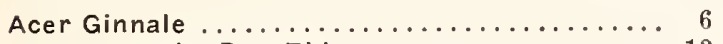

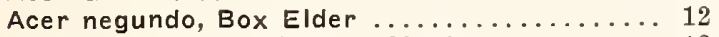

Acer platanoides, Norway Maple .......... 12

Acer rubrum, Red Maple ............... 6

Aesculus hippocastanum, Horse Chestnut .... 8

Althaea anemonaeflora, double pink .......

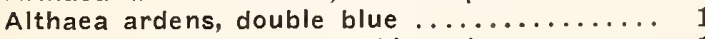

Althaea Boule de Feu, double red ........... 1

Althaea Jean de Arc, double white ..........

Althaea purpurea semi-plena, semi-double

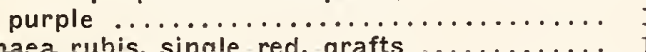

Althaea rubis, single red, grafts $\ldots \ldots \ldots \ldots \ldots$
Althaea totus albus, single white $\ldots \ldots \ldots \ldots$

Althaea variegated leaved, grafts ...........6 6

Althaea variegated leaved, grafts. .......... 12

Amelanchier canadensis, Juneberry ......... 12

Ampelopsis Englemanni, Englemann's Ivy ... 1

Ampelopsis quinquefolia. Virginia creeper ... 1

Aralia pentaphylla ................. 1

Berberis Thunbergii, Japanese Barberry .... 6

Betula nigra (rubrum), red or River Birch .. 6

Betula nigra (rubrum), red or River Birch .. 12

Calycanthus floridus, Sweet Shrub ........ 6

Caragana arborescens, Siberian Pea ....... 12

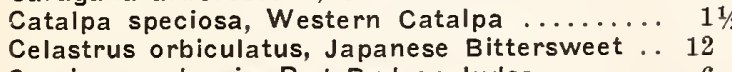

Cercis canadensis, Red Bud or Judas ...... 6

Cladastris tinctoria, Yellow-wood ............ 1

Clethra alnifolia, Sweet-Pepper bush ....... 10

Cornus sericea, Silky Dogwood .............. 1

Cornus Siberica (alba), red stemmed Dogwood

Cornus stolonifera lutea, yellow stemmed Dog-

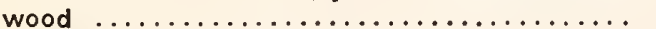

Grataegus coccinea, Scarlet Thorn ......... 4

Cydonia Japonica, Japanese Quince ......... 1

Deutzia candidissima, double white ......... 1

Deutżia crenata rosea plena, double pink ..... 1

$\begin{array}{lrrr} & \text { Per } 10 & \text { Per } 100 & \text { Per } 1000 \\ \text { to } 12 \text { in. } & .50 & 3.50 & 30.00 \\ \text { to } 18 \text { in. } & .35 & 3.00 & 25.00 \\ \text { to } 18 \text { in. } & .65 & 5.50 & 50.00 \\ \text { to } 12 \text { in } & .50 & 3.50 & 30.00 \\ \text { to } 12 \text { in. } & .50 & 4.00 & 35.00 \\ \text { year } & .50 & 4.50 & 40.00 \\ \text { year } & .50 & 4.50 & 40.00 \\ \text { year } & .50 & 4.50 & 40.00 \\ \text { year } & .50 & 4.50 & 40.00 \\ & & & \\ \text { year } & .50 & 4.50 & 40.00 \\ \text { year } & 1.25 & 10.00 & \\ \text { year } & .50 & 4.50 & 40.00 \\ \text { to } 12 \text { in. } & 1.00 & 8.50 & 70.00 \\ \text { to } 15 \text { in. } & 1.25 & 10.00 & 80.00 \\ \text { to } 18 \text { in } & .50 & 4.50 & 40.00 \\ \text { year } & .50 & 3.50 & 30.00 \\ \text { year } & .50 & 3.50 & 30.00 \\ \text { year } & .50 & 3.50 & 30.00 \\ \text { to } 9 \text { in } & .35 & 1.25 & 10.00 \\ \text { to } 12 \text { in. } & .35 & 3.00 & 25.00 \\ \text { to } 18 \text { in. } & .50 & 3.50 & 30.00 \\ \text { to } 12 \text { in } & .50 & 4.50 & 40.00 \\ \text { to } 18 \text { in. } & .50 & 3.50 & 30.00 \\ \text { to } 2 \mathrm{ft} . & .35 & 2.00 & 15.00 \\ \text { to } 18 \mathrm{in.} & .50 & 4.00 & 35.00 \\ \text { to } 12 \mathrm{in} & .50 & 3.50 & 30.00 \\ \text { to } 11 / 2 \mathrm{ft} . & .50 & 4.50 & 40.00 \\ \text { to } 15 \mathrm{in} . & .50 & 4.50 & 40.00 \\ \text { year } & .50 & 4.00 & 35.00 \\ \text { year } & .50 & 4.00 & 35.00 \\ \text { year } & .50 & 4.00 & 35.00 \\ \text { to } 6 \text { in. } & .50 & 4.00 & 35.00 \\ \text { year } & .50 & .4 .50 & 40.00 \\ \text { year } & .50 & .4 .00 & 35.00 \\ \text { year } & .50 & .4 .00 & 35.00\end{array}$


Deutzia Pride of Rochester, double pink ..... 1 Eleagnus angustifolia, Russian Olive ........ 12 Fagus ferruginea, American Beech ......... 12

Forsythia Fortunei, Golden Bell ........... 1

Forsythia intermedia, Golden Bell ......... 1

Forsythia viridissima, Golden Bell .......... 1

Gleditschia triacanthos. Honey Locust ...... 12

Hamamelis Virginica, Witch Hazel ......... 12 Hydrangea paniculata (type), single ......... 1 Juglans nigra, Black Walnut ............. 12 Juglans cineria, White Walnut or Butternut .. 12 Laburnum vulgare, Golden Chain ........... 2 Ligustrum Amoor North, upright, hardy Privet Ligustrum ibota, drooping Privet .......... 9 Ligustrum vulgare, English or Common Privet 4 Ligustrum vulgare, English or Common Privet 7 Liquidambar styraciflua, Sweet Gum ....... 12 Liriodendron tulipifera, Tulip Tree ......... 12 Lonicera fragrantissima, fragrant Bush Honey-

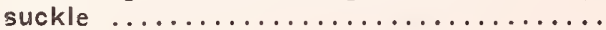

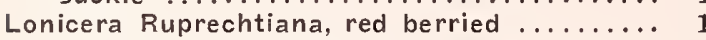

Lonicera Scarlet Trumpet ............... 1

Lonicera tatarica alba, white bush honeysuckle Oxydendron arboreum, Sourwood ...........

Philadelphus coronarius, sweet flowered Mock

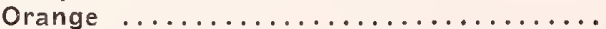

Philadelphus grandiflorus, large flowered Mock

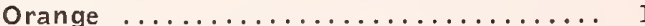

Philadelphus Mt. Blanc, white .......... 12

Populus fastigiata, Lombardy Poplar ......... 12

Populus monolifera, Carolina Poplar or Cotton-

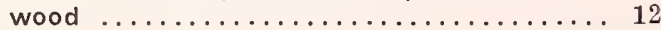

Rhamnus catharticus, Buckthorn .......... 10

Rhodotypos kerroides ................ 10

Rhus copallina .................... 12

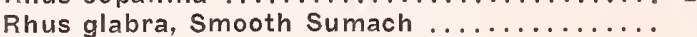

Rhus typhina, Stag Horn Sumach $\ldots \ldots \ldots \ldots \ldots$....
Robinia pseudo acacia, Yellow or Black Locust

Robinia pseudo acacia, Yellow or Black Locust

Robinia pseudo acacia, Yellow or Black Locust Robinia pseudo acacia, Yellow or Black Locust

Rosa multiflora Japonica, Polyantha Rose .... 12

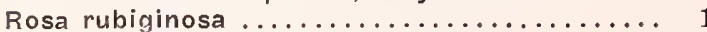

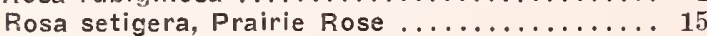

Sambucus canadensis, Elderberry ......... 12

Spiraea Douglassi, pink ................ 1

Spiraea opulifolia, Ninebark ............. 1

Spiraea opulifolia aurea, Golden Leaf ........ 1

Spiraea Van Houttei, single white ..........

Symphoricarpus molle, large white Snowberry Symphoricarpus racemosus, white Snowberry 1 Symphoricarpus vulgaris, Coral Berry ....... Tamarix Africana, light pink, early ........ Tamarix Gallica, light pink, early .......... UImus Americana, American Elm ..........

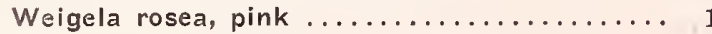

Zanthorhiza apiifolia, Yellowroot .......... 12

\section{year}

to $18 \mathrm{in}$

to $18 \mathrm{in}$

year

year

year

to $18 \mathrm{in}$.

to $18 \mathrm{in}$

year

to $18 \mathrm{in}$

to $18 \mathrm{in}$.

year

to $12 \mathrm{in}$.

to $12 \mathrm{in}$

to $6 \mathrm{in}$.

to $9 \mathrm{in}$

to $18 \mathrm{in}$

to $18 \mathrm{in}$.

year

year

year

year

to $12 \mathrm{in}$

year

year

to $18 \mathrm{in}$.

to $18 \mathrm{in}$.

to $18 \mathrm{in}$.

to $12 \mathrm{in}$.

to $12 \mathrm{in}$.

to $18 \mathrm{in}$.

to $2 \mathrm{ft}$.

to $3 \mathrm{ft}$.

to $11 / 2 \mathrm{ft}$

$1 / 2$ to $2 \mathrm{ft}$.

to $3 \mathrm{ft}$.

to $4 \mathrm{ft}$.

to $18 \mathrm{in}$.

year

to $18 \mathrm{in}$.

to $15 \mathrm{in}$.

year

year

year

year

year

year

year

year

year

$1 / 2$ to $2 \mathrm{ft}$.

year

to $18 \mathrm{in}$.
Per 10 Per 100 Per 1000

$50-4.00-35.00$

$\begin{array}{lll}.50 & 3.50 \quad 30.00\end{array}$

$\begin{array}{lll}.50 & 4.00 \quad 35.00\end{array}$

$\begin{array}{lll}.50 & 4.00 \quad 35.00\end{array}$

$\begin{array}{lll}50 & 4.00 \quad 35.00\end{array}$

$\begin{array}{lll}.50 & 4.00 \quad 35.00\end{array}$

$\begin{array}{lll}.35 & 2.50 & 20.00\end{array}$

$.50 \quad 4.50 \quad 40.00$

$\begin{array}{lll}.50 & 4.00 \quad 35.00\end{array}$

$\begin{array}{lll}.50 & 3.50 \quad 30.00\end{array}$

$\begin{array}{lll}.50 & 3.50 & 30.00\end{array}$

$\begin{array}{lll}.65 & 5.00 & 45.00\end{array}$

$\begin{array}{lll}.35 & 3.00 & 25.00\end{array}$

$\begin{array}{lll}.35 & 2.50 \quad 20.00\end{array}$

$\begin{array}{lll}.25 & 1.50 & 10.00\end{array}$

$\begin{array}{lll}.35 & 2.00 & 15.00\end{array}$

$\begin{array}{lll}.50 & 4.00 \quad 35.00\end{array}$

$.50 \quad 3.50 \quad 30.00$

$\begin{array}{lll}.50 & 4.00 \quad 35.00\end{array}$

$\begin{array}{lll}.50 & 4.00 \quad 35.00\end{array}$

$\begin{array}{lll}.50 & 4.00 & 35.00\end{array}$

$\begin{array}{lll}.50 & 4.00 & 35.00\end{array}$

$\begin{array}{lll}.65 & 5.50 \quad 50.00\end{array}$

$.50 \quad 4.00 \quad 35.00$

$\begin{array}{lll}.50 & 4.00 \quad 35.00\end{array}$

$\begin{array}{lll}.50 & 4.50 \quad 40.00\end{array}$

$\begin{array}{lll}.35 & 2.50 & 20.00\end{array}$

$\begin{array}{lll}.35 & 2.50 \quad 20.00\end{array}$

$\begin{array}{lll}.50 & 3.50 \quad 30.00\end{array}$

$\begin{array}{lll}.50 & 4.50 \quad 40.00\end{array}$

$\begin{array}{lll}.50 & 3.50 \quad 30.00\end{array}$

$\begin{array}{lll}.35 & 3.00 & 25.00\end{array}$

$\begin{array}{lll}.35 & 3.00 & 25.00\end{array}$

$\begin{array}{lll}.25 & 1.25 & 8.00\end{array}$

$\begin{array}{lll}.25 & 1.50 & 10.00\end{array}$

$\begin{array}{lll}.35 & 2.00 \quad 15.00\end{array}$

$\begin{array}{lll}.50 & 3.00 & 25.00\end{array}$

$\begin{array}{lll}.35 & 3.00 & 25.00\end{array}$

$\begin{array}{lll}.50 & 3.50 & 30.00\end{array}$

$.50 \quad 3.50 \quad 3000$

$\begin{array}{lll}.50 & 3.50 \quad 30.00\end{array}$

$\begin{array}{lll}.50 & 4.00 & 35.00\end{array}$

$\begin{array}{lll}50 & 4.00 \quad 35.00\end{array}$

$.50 \quad 4.00 \quad 35.00$

$\begin{array}{lll}50 & 4.00 \quad 35.00\end{array}$

$.50 \quad 4.00 \quad 35.00$

$\begin{array}{lll}50 & 4.00 & 35.00\end{array}$

$\begin{array}{lll}.50 & 4.00 & 35.00\end{array}$

$.50 \quad 4.00 \quad 35.00$

$.50 \quad 4.00 \quad 35.00$

$\begin{array}{lll}.35 & 2.50 & 20.00\end{array}$

$.65 \quad 5.00$

$\begin{array}{lll}.50 & 4.00 \quad 35.00\end{array}$

\section{RAF F I A}

We are HEADQUARTERS for Raffia for budding and tying purposes and our brands are the STANDARD of the Raffia market.

The LEADING nursery firms demand the best-A. A. Westcoast,-others find X. X. Superior or Red Star suitable for their purpose.

Send for our prices before buying, or better still, just place your order with us and we will give you our best price.

\section{NURSERY SUPPLIES}

We carry in stock a full line of Spades, Pruning and Budding Knives, Pruning Shears and Tree Calipers. Write for price list.

\section{DOMESTIC CANES}

Fine for staking young trees. 9 to 12 feet long, $1 / 2$ to $3 / 4$ inch at butt, tapering to point at top. 200 canes in a bale.

$\$ 9.00$ per bale of 200.10 bales or over, $\$ 8.75$ per bale. 